\title{
Kajian Kemampuan Pemecahan Masalah Siswa dalam Menyelesaikan Soal Sistem Persamaan Linear Dua Variabel
}

\author{
Sri Hartina ${ }^{1}$, Sanapiah ${ }^{2}$, Baiq Rika Ayu Febrilia ${ }^{3}$ \\ ${ }^{1,2,3}$ Program Studi Pendidikan Matematika, FSTT, Universitas Pendidikan Mandalika \\ Penulis Korespondensi: srihartina0412@gmail.com
}

\begin{abstract}
The process of students' problem solving abilities is marked by each step of problem solving given by the student. The purpose of this study was to describe the problem solving ability of students in solving the problems of the Two Variable Linear Equation System in class VIII students. The problem solving steps according tu Polya. Based on Polya (1973) there are four stages used by students in problrms solving, namely (1) understanding the problem, (2) preparing a settlement plan, (3) implementing a settlement plan, and (4) re-examining. This type of research is descriptive research with a qualitative approach. The subjects of this study were student of class VIII SMPN 18 Mataram as many as 3 students, one student with high ability, one student with moderate ability, and one studen with low ability. The instrument of this research is a written test using story question sheets in the form of descripstion questions. The results obtained in this study are: (1) problem solving abilities for highability students are included in the low category, in understanding the problem they are still wrong, but can arrange solutions, carry out settlement plans and re-examine the results of he settlement; (2) problem solvig abilities for moderately capable students are included in the very low category, in understanding the problem they are still wrong, but they can arrange solutions, do not properly implement the settlement plan and re-examine the results of the settlement; (3) problem-solving abilities for low-ability students are ncluded in the very low category, in understanding the problrm they do not write down what is known and what is asked, do not develop a settlement plan, and re-examine the results of the settlement.
\end{abstract}

Keywords: study of problem solving ability, story problems, two variable linear equation system.

\begin{abstract}
Abstrak: Proses kemampuan pemecahan masalah siswa ditandai oleh setiap langkah penyelesaian masalah yang diberikan oleh siswa tersebut. Tujuan penelitian ini adalah untuk mendeskripsikan kemampuan pemecahan masalah siswa dalam menyelesaikan soal Sistem Persamaan Linear Dua Variabel pada siswa kelas VIII. Langkah-langkah penyelesaian masalah yang digunakan dalampenelitian ini adalah langkah-langkah menurut Polya. Berdasarkan Polya (1973) terdapat empat tahapan yang digunakan siswa dalam penyelesaian masalah, yaitu (1) memahami masalah, (2) menyusun rencana penyelesaian, (3) melaksanakan rencana penyelesaian, dan (4) memeriksa kembali. Jenis penelitian ini adalah penelitian deskriptif dengan pendekatan kualitatif. Subjek penelitian ini adalah siswa kelas VIII SMPN 18 Mataram sebanyak 3 siswa, satu siswa berkemampuan tinggi, satu siswa berkemampuan sedang, dan satu siswa berkemampuan rendah. Instrumen penelitian ini adalah tes tertulis menggunakan lembar soal cerita berbentuk soal uraian. Hasil yang diperoleh pada penelitian ini adalah: (1) kemampuan pemecahan masalah untuk siswa berkemampuan tinggi termasuk dalam katagori rendah, dalam memahami masalah masih keliru, tetapi dapat menyusun penyelesaian, melaksanakan rencana penyelesaian dan memeriksa kembali hasil penyelesaian; (2) kemampuan pemecahan masalah untuk siswa berkemampuan sedang termasuk dalam katagori sangat rendah, dalam memahami masalah masih keliru, tetapi dapat menyusun penyelesaian, kurang tepat melaksanakan rencana penyelesaian dan memeriksa kembali hasil penyelesaian; (3) kemampuan pemecahan masalah untuk siswa berkemampuan rendah termasuk dalam katagori sangat rendah, dalam memahami masalah tidak menuliskan apa yang diketahui dan apa yang ditanyakan, tidak menyusun rencana penyelesaian, tetapi dapat melaksanakan rencana penyelesaian, dan memeriksa kembali hasil penyelesaiannya.
\end{abstract}

Kata kunci: kajian kemampuan pemecahan masalah, soal cerita, sistem persamaan linear dua variabel. 


\section{PENDAHULUAN}

Menurut Departemen Pendidikan Nasional (Depdiknas), tujuan adanya pembelajaran matematika untuk memecahkan masalah di mana masalah yang dapat meliputi kemampuan memahami masalah matematika, membuat model matematika, menyelesaikan model matematika, dan menafsirkan kembali solusi yang diperoleh. Kemampuan pemecahan masalah ini dirasakan sangat penting karna hampir di semua Standar Kompetensi dan Kompetensi Dasar ditemui. Pemecahan masalah yaitu suatu usaha yang dilakukan oleh siswa untuk mencari jalan keluar atas masalah yang sedang dihadapi (Polya, 1973). Dengan adanya kemampuan pemecahan masalah, siswa memiliki kemampuan mencari solusi dan lebih antisipatif untuk menghadapi kemungkinan yang akan terjadi (Norlismasari, Johar \& Yuzrizal, 2017). Pemecahan masalah bisa merangsang keterampilan berpikir siswa dengan melatih siswa berpikir (Ngilawajan, 2013), di mana siswa di haruskan untuk melakukan kegiatan berpikir untuk menangani atau mencari penyelesaian dari masalah atau pertanyaan yang sedang diterima (Yani, Ikhsan \& Marwan, 2016) dengan menggunakan pengetahuan atau keterampilan yang telah dimiliki sebelumnya.

Dalam menyelesaikan masalah, proses kemampuan pemecahan masalah siswa diperlihatkan melalui langkah-langkah menyelesaikan masalah yang diberikan oleh siswa tersebut (Yanti \& Syazali, 2016). Salah satu tahapan penyelesaian masalah yang dipakai adalah tahapan menurut Polya. Berdasarkan Polya (1973) terdapat empat tahapan yang dapat dipakai siswa dalam menyelesaikan masalah, yaitu (1) memahami masalah, (2) menyusun rencana penyelesaian, (3) melaksanakan rencana penyelesaian, dan (4) memeriksa kembali. Tahapan menyelesaikan masalah menurut Polya (lihat Tabel 1) dapat membantu agar siswa tidak hanya mengikuti ingatan saat menangani soal-soal matematika, tetapi siswa diinginkan dapat menggabungkan dengan situasi berwujud yang sudah dialaminya atau yang sudah dipikirkannya. Siswa juga diharapkan memiliki sikap memuliakan kegunaan matematika pada kehidupan, yakni memiliki rasa keingintahuan, perhatian dan keinginan mempelajari serta sikap gigih dan kukuh saat memecahkan masalah. Tahapan Polya juga bisa memfasilitasi siswa saat membimbing pemikiran siswa agar memperoleh solusi atas kesulitan yang dihadapi (Anwar \& Amin, 2013).

Penilaian komparatif internasional baru-baru ini, seperti PISA, menunjukkan bahwa siswa Indonesia berada di tingkat 72 dari 78 dalam matematika (Schleider, 2019) sedikitnya skor matematika salah satu aspek penilaian maupun soal yang dibagikan di Indonesia minimal di level bawah. Menurut pendapat Taksonomi Bloom klasifikasi ranah proses berpikir diklasifikasikan menjadi enam katagori, yaitu: memikirkan $(\mathrm{C} 1)$ menguasai (C2), mengamalkan (C3), menguraikan (C4), menguji (C5), dan mendesain (C6) (Krathwohl, 2002). Di sekolah Indonesia siswa cuma terbiasa membagikan soal pada tingkat $\mathrm{C}$, $\mathrm{C} 2$, dan setengah $\mathrm{C}$, padahal soal tes berstandar Internasional PISA bukan cuma soal yang menilai kemampuan penyelesaian masalah pada soal biasa, tetapi di sini akan memerhatikan kemampuan siswa saat memecahkan masalah, mulai dari mengkajinya, merumuskannya dan menginformasikan usulannya untuk orang lain. Dari 
sekala keterampilan enam level PISA lebih dari 50\% siswa Indenesia tidak sampai level terendah, dan kemampuan pemecahan masalahnya yaitu kurang dari negara yang mengikuti.

Oleh karena itu, berdasarkan pengalaman membimbing di sekolah (PPL) di SMP kelas VIII dan hasil kunjungan dengan guru matematika siswa masih relatif sangat rendah. Tes hasil belajar pada materi Sistem Persamaan Linear Dua Variabel menyatakan bahwa hanya 32,05\% siswa yang di nyatakan tuntas dengan standar KKM mata pelajaran matematika adalah 70 .

Pemecahan masalah dalam matematika umumnya diwujudkan dengan soal cerita yang dalam menyelesaikannya terlebih dahulu siswa mesti dapat menguasai isi soal cerita tertera, sesudah itu siswa menyusun rencana menyelesaikannya, membuat rencana penyelesaian dan sampai pada tingkat akhir yaitu memverifikasi kembali penyelesaian. Untuk penyelesaian soal cerita bukan segampang menyelesaikan soal yang telah terbentuk simbol. Dalam mengerjakan siswa di diharapkan untuk bisa mengganti kalimat matematika membentuk simbol matematika, karna itulah kemampuan pemecahan masalah sangat diperlukan.

Dari uraian di atas dan lantaran kecilnya prestasi siswa Indonesia dalam PISA dan kemampuan pemecahan masalah siswa dalam menyelesaikan soal yang bertautan dengan PISA peneliti tertarik agar membuat judul Kajian Kemampuan Pemecahan Masalah Siswa dalam Menyelesaikan Soal Sistem Persamaan Linear Dua Variabel Kelas VIII SMPN 18 Mataram.

\section{METODE}

Jenis penelitian ini adalah penelitian deskriptif. Jenis penelitian deskriptif kualitatif menerjemahkan data berdasarkan dengan situasi dan kondisi yang terjadi. Penelitian deskriptif kualitatif mencerminkan situasi yang sebenarnya tanpa menambahnambahkan dan rekayasa pada variabel. Pada penelitian ini, data yang di deskripsikan adalah kemampuan siswa dalam menyelesaikan soal Sistem Persamaan Linear Dua Variabel.

Dalam penelitian ini, subjek penelitian adalah 3 siswa kelas VIII SMP Negeri 18 Mataram yang terdiri satu siswa berkemampuan tinggi, satu siswa berkemampuan sedang, dan satu siswa berkemampuan rendah.

Instrumen yang digunakan adalah soal tes. Soal tes merupakan tes yang dirancang untuk keperluan menganalisis kemampuan pemecahan masalah siswa dalam menyelesaikan soal Sistem Persamaan Linear Dua Variabel. Berdasarkan hasil tes tersebut dapat diidentifikasi pemahaman siswa dalam menyelesaikan soal Sistem Persamaan Linear Dua Variabel.

SOAL 
1. Harga 2 pensil dan 3 penggaris Rp.6.000,00, sedangkan harga 4 pensil dan 2 penggaris Rp.8.000,00. Tentukan harga 3 pensil dan 2 penggaris!

2. Lisa dan Muri bekerja pada pabrik tas. Lisa dapat menyelesaikan 3 buah tas setiap jam dan Muri dapat menyelesaikan 4 tas setiap jam. Jumlah jam kerja Lisa dan Muri adalah 16 jam sehari dengan jumlah tas yang dibuat oleh keduanya adalah 55 tas. Jika jam kerja keduanya berbeda, tentukan jam kerja mereka masingmasing!

Data dalam penelitian ini berarti informasi atau fakta yang diperoleh melalui pengamatan atau penilaian di lapangan yang bisa dianalisis dalam rangka memahami sebuah fenomena atau untuk mendukung sebuah teori. Untuk mengetahui kemampuan siswa pada proses pemecahan masalah Sistem Persamaan Linear Dua Variabel maka peneliti melakukan penelitian dengan menggunakan teknik pengumpulan data yaitu tes tertulis menggunakan lembar soal. Terdiri atas 2 soal, soal cerita berbentuk essay.

Berikut ini merupakan langkah-langkah yang dilakukan dalam memecahkan suatu permasalahan dalam matematika menurut Polya.

\section{HASIL DAN PEMBAHASAN}

Hasil yang diperoleh dalam penelitian ini berupa kemampuan pemecahan masalah siswa dalam menyelesaikan soal SPLDV dalam bentuk soal cerita. Berdasarkan hasil tes di ketahui bahwa sebagian besar siswa tidak mampu menyelesaikan soal yang dinerikan. Pada bagian ini akan dijelaskan lebih lanjud mengenai gambaran kemampuan pemecahan masalah siswa berdasarkan tahapan Polya pada setiap siswa yang dikategorikan berdasrkan kemampuan awal matematkannya.

Berikut ini merupakan langkah-langkah yang dilakukan dalam memecahkan suatu permasalahan dalam matematika menurut Polya.

\section{Langkah I. Memahami masalah}

Pada langkah ini siswa menuliskan data yang diperlukan dan menuliskan inti permasalahan.

1. Siswa $1\left(S_{1}\right)$

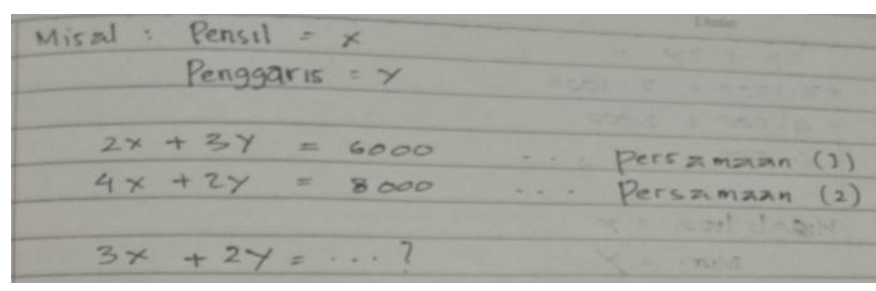

Gambar 1. Jawaban soal nomor 1 
Berdasarkan Gambar 4.1 $\mathrm{S}_{1}$ menuliskan barangnya sebagai variabel $\mathrm{x}$ dan $\mathrm{y}$, padahal untuk variabel itu yang harus di tuliskan bentuk kuantitasnya misalkan, seperti banyaknya pensil atau harga pensil. Kemudian $S_{1}$ sudah bisa melakukan pemodelan tapi di pemodelan ini tidak ada keterangan bahwa dia menerjemahkan misalkan $2 \mathrm{x}$ itu apa 3y 3 kali apa sehingga kita tidak tau dari diannya sudah cukup paham atau tidak, atau sembarang menulis $2 x+3 y$ intinya $S_{1}$ sudah bisa memodelkan terlihatnya. Tapi, penapsiran dari hasil pemodelannya masih belum jelas dia pahami atau tidak karna kita tidak sempat melakukan wawancara. Tapi kita juga belum bisa menelusuri apakah maksud dari $3 x+2 y$ nya ini.

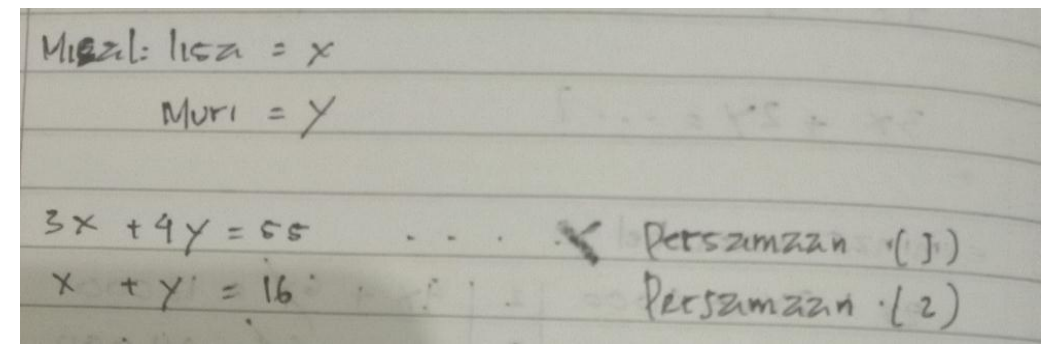

Gambar 2. Jawaban soal nomor 2

Berdasarkan Gambar 4.2 pada soal nomor 2 ini $S_{1}$ masih keliru pemisalannya padahal untuk variabelnya itu yang harus di tulis bentuk kuantitasnya misalkan seperti jam kerja lisa atau jam kerja murni.

Kemudian $\mathrm{S}_{1}$ sudah bisa melakukan pemodelan tapi di pemodelan ini tidak ada keterangan bahwa $S_{1}$ menerjemahkan misalkan $3 x$ itu apa $4 y+$ kali apa sehingga kita tidak tau $S_{1}$ sudah cukup paham atau tidak, atau sembarang menulis $3 x+4 y$ intinya $S_{1}$ sudah bisa memodelkan terlihatnya. Tapi, penapsiran dari hasil pemodelannya masih belum jelas dia pahami atau tidak karna kita tidak sempat melakukan wawancara.

2. Siswa $2\left(\mathrm{~S}_{2}\right)$

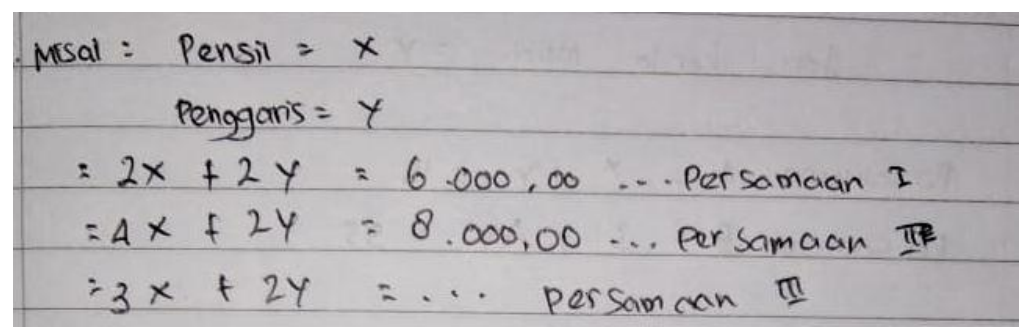

Gambar 3. Jawaban soal nomor 1 
Berdasarkan Gambar 4.3 $\mathrm{S}_{2}$ memisalkan barangnya yang mana itu juga salah. Soal nomor 1 ini masih keliru pemisalannya kemudian $\mathrm{S}_{2}$ juga salah dalam menuliskan dimana dia memulai menggunakan tanda sama dengan padahal tanda ini untuk hubungan ekupalensi antara ruas kiri dan ruas kanan sedangkan ruas kiri tidak ada apaapa, tiba-tiba sudah menulis sama dengan. Ini hal yang tidak perlu dilakukan oleh $\mathrm{S}_{2}$ disini. Kemudian $2 x+2 y$ ini juga $S_{2}$ sudah menuliskan dalam bentuk pemodelan tapi disini $\mathrm{S}_{2}$ keliru. Ada kekeliruan yang terjadi pada penulisan pemodelan yang pertama. Kemudian selanjutnya $3 x+2 y$ ini $S_{2}$ tidak jelaskan apakah ini yang di tanyakan atau tidak tiba-tiba $\mathrm{S}_{2}$ menulis bersamaan dengan yang di atas tadi sama dengan titik titikdi kosongkan.

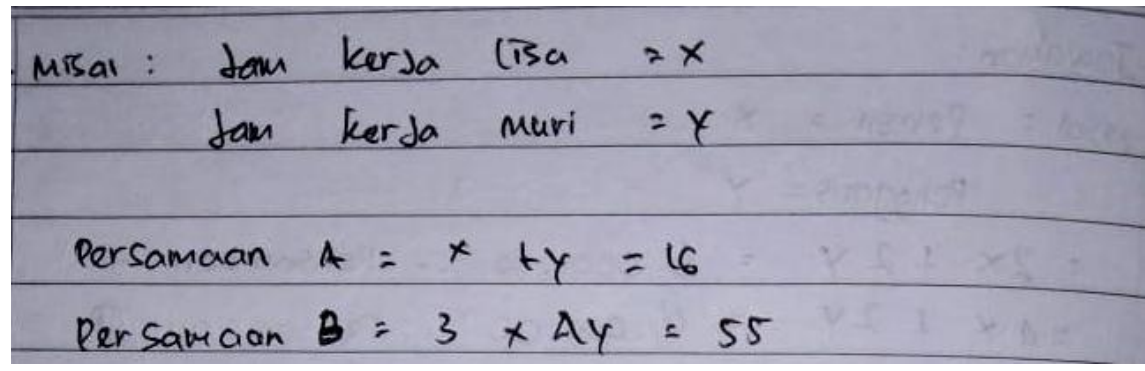

Gambar 4. Jawaban soal nomor 2

Berdasarkan Gambar 4.4 $\mathrm{S}_{2}$ sudah bagus dalam pemisalannya atau sudah di jam kerjanya disini dan ini sudah tepat untuk pemisalannya. Kemudian disini ada kesalahan menulis persamaan $\mathrm{a}=\mathrm{x}+\mathrm{y}=16$ sebenarnya cukup menulis

$\mathrm{x}+\mathrm{y}=16$ ini saja jadi nantinya keliru. Nanti timbul pemikiran apa persamaan $\mathrm{a}=\mathrm{x}+\mathrm{y}$ $=16$ ini di pikirnya hubungannya sama antara yang kiri dan yang kanan padahal tidak boleh.

\section{Siswa $3\left(\mathrm{~S}_{3}\right)$}

$\mathrm{S}_{3}$ disini tidak menuliskan ini jadi kita tidak paham apakah dia mengetahui apa yang di ketahui dan ditanyakan tetapi ketika ditelusuri jawabannya bagaimana nanti kita cek lagi kalau di salah jawabannya jelas salah karnakan $S_{3}$ tidak menuliskan diketahui dan ditanyakannya. 


\section{Langkah II. Merencanakan penyelesaian}

Dalam perencanaan penyelesaian ini tidak bisa kita telusuri terlebih jauh karna yang di analisis adalah lembar kerja siswanya yang mana pada lembar kerja itu sebenarnya sudah si siswa atau sih sabjek penelitian ini sudah langsung melakukan rencana penyelesaiannya. Kalau untuk rencana ini seharusnya ditanyakan sebelum siswa mengerjakan tetapi ketidak mampuan kita dalam mewawancarai siswa kita tidak bisa mengetahui secara pasti sebelumnya siswa rencanakan. Sehingga, kita bisa menganalisisnya melalui tahap pelaksanaannya saja dan hasilnnya adalah misalkan siswa $\mathrm{S}_{1}$ menggunakan metode campuran dan substitusi.

Sama juga dengan $S_{2}$ hal ini dapat dilihat dari langkah pertama misalkan harus disuebut langkah pertama pengeliminasian variabel yang kemudian di lanjutkan dengan persubstitusian hasil eliminasi yang dilakukan tadi dari hasil variabel terntentu yang di peroleh dari hasil eliminasi dari hasil variabel lainnya itu yang di substitusi.

Kemudian $\mathrm{S}_{3}$ menggunakan metode substitusi dengan langsung memasukan nilai dari variabel-variabelnya.

\section{Langkah III. Melakukan rencana penyelesaian}

1. Siswa $1\left(\mathrm{~S}_{1}\right)$

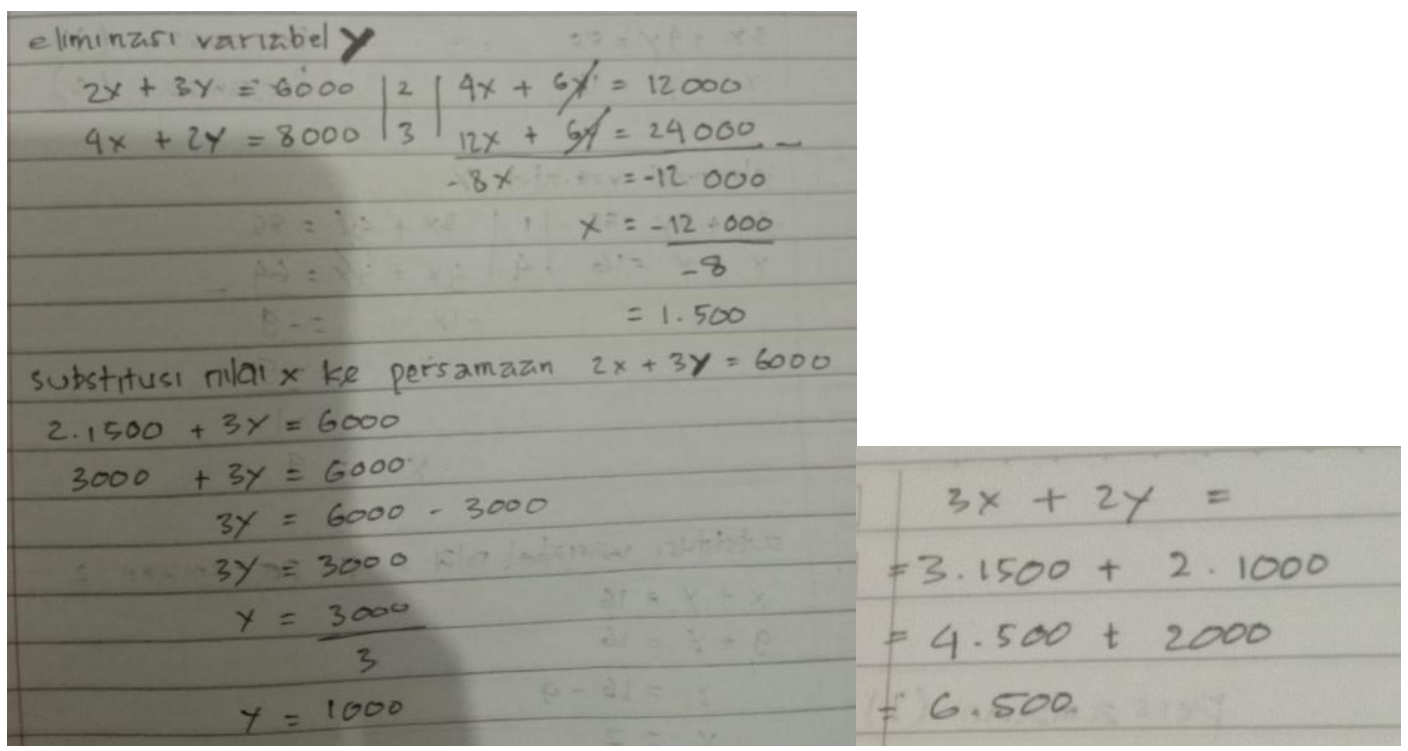

Gambar 5. Jawaban soal Nomor 1 
Berdasarkan Gambar.4.5 $\mathrm{S}_{1}$ menyelesaikan soal dengan cara mengeliminasi varibel y terlebih dahulu untuk memperoleh nilai variabel $\mathrm{x}$ kemudian menggunakan metode substitusi untuk mencari nilai variabel $x$. Setelah mendapatkan kudua nilai variabel tersebut $\mathrm{S}_{2}$ kemudian mensubstitusikan nilai kedua variabel untuk mendapatkan hasilnya.

Kemudain untuk mendapatkan hasil dengan cara mensubstitusikan nilai dari variabel $\mathrm{x}$ dan y $S_{1}$ memulai menggunakan tanda sama dengan padahal tanda sama dengan ini untuk hubungan ekupalensi antara ruas kiri dan ruas kanan. Sedangkan ruas kiri tidak ada apa-apa tiba-tiba menuliskan sama dengan, ini hal yang tidak perlu dilakukanoleh $\mathrm{S}_{1}$ disini.

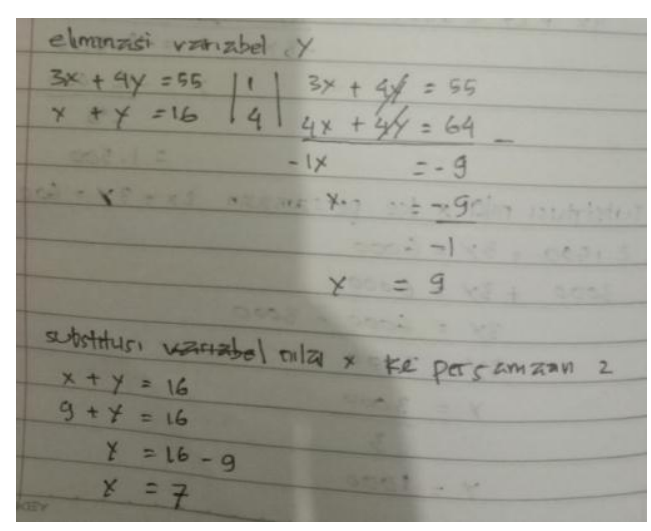

Gambar 6. Jawaban soal nomor 2

Berdasarkan gambar 4.6 $\mathrm{S}_{1}$ menyelesaikan soal dengan cara mengeliminasi variabel y terlebih dahulu untuk memperoleh nilai variabel $\mathrm{x}$ kemudian menggunakan metode substitusi untuk mencari nilai variabel y.

2. Siswa $2\left(\mathrm{~S}_{2}\right)$

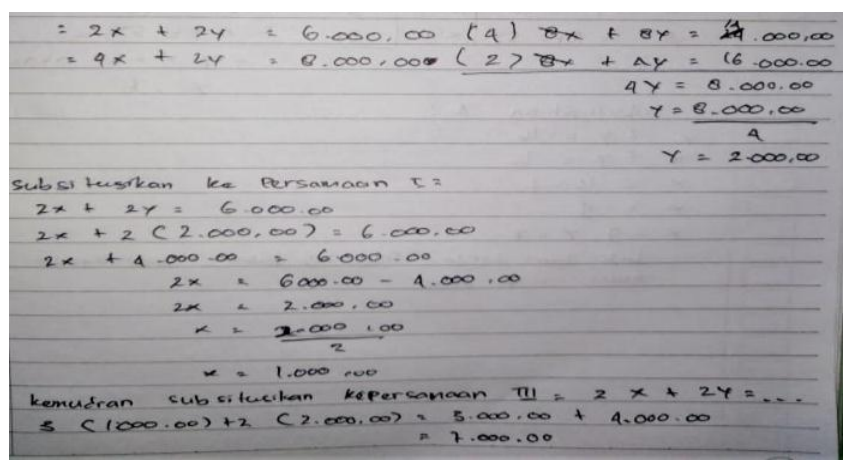

Gambar 7. Jawaban soal nomor 1 
Berdasarkan Gambar 4.7 $\mathrm{S}_{2}$ menyelesaikan soal dengan cara mengeliminasi variabel y terlebih dahulu untuk memperoleh nilai vaiabel y kemudian menggunakan metode substitusi untuk mencari nilai variabel x. Setelah mendapatkan kedua nilai variabel tersebut $\mathrm{S}_{1}$ kemudian mensubstitusikan nilai kedua variabel untuk mendapatkan hasilnya. Pada tahap pengeliminasian variabel $\mathrm{x}$ untuk mendapatkan nilai variabel y disini benar, namun dia salah dalam menuliskan tanda sama dengan, dia memulai menggunakan tanda sama dengan padahal tanda sama dengan ini untuk hubungan ekupalensi antara ruas kanan dan ruas kiri . sedangkan ruas kiri tida ada apa-apa, tibatiba $S_{2}$ menuliskan sama dengan, ini hal yang tidak perlu di lakukan oleh $S_{2}$ disini.

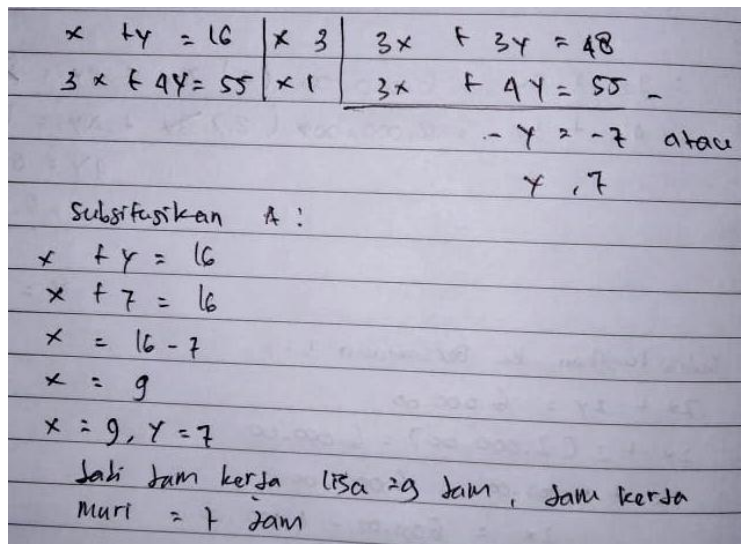

Gambar 8. Jawaban nomor 2

Berdasarkan Gambar 4.8 $\mathrm{S}_{2}$ menyelesaikan soal dengan cara mengeliminasi variabel $\mathrm{x}$ terlebih dahulu untuk memperoleh nilai variabel y kemudian menggunakan menggunakan metode substitusi untuk mencari nilai variabel $\mathrm{x}$.

3. Siswa $2\left(\mathrm{~S}_{2}\right)$

$3 x+2 y=$

$3(1500)+2(1000)$

$4500+2000=6500$

Gambar 9. Jawaban soal nomor 1

Berdasarkan Gambar 4.9 $\mathrm{S}_{3}$ menyelesaikan soal dengan cara mensubstitusikan nilai $\mathrm{x}$ dan y untuk mendapatkan hasilnya. Namun untuk yang $S_{3}$ ini, $S_{3}$ tidak menuliskan cara mendapatkan nilai variabel $\mathrm{x}$ dan y jadi kita tidak paham apakah $\mathrm{S}_{3}$ mengetahui apa 
yang di ketahui dan ditanyakan. Tetapi, ketika di telusi jawabannya berhasil mengerjakan jawaban dengan hasil yang benar atau seharusnya.

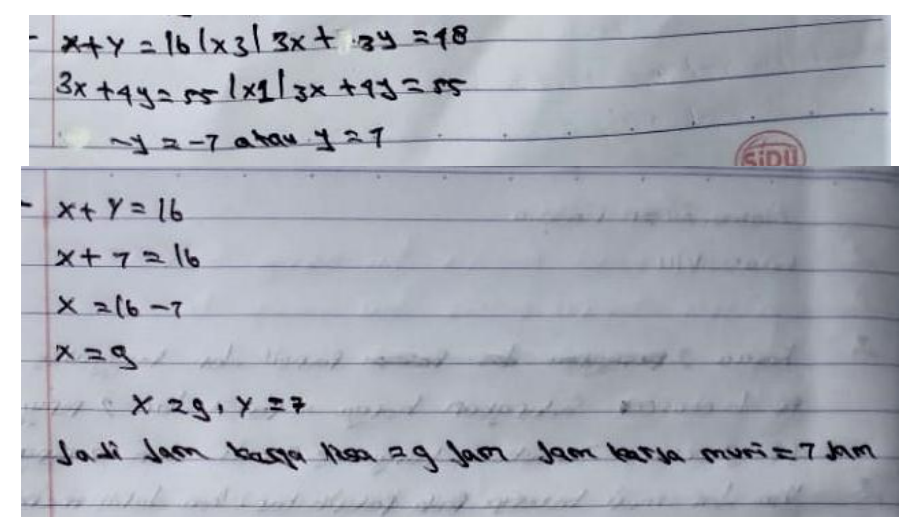

Gambar 10. Jawaban nomor 2

Berdasarkan Gambar 4.10 $\mathrm{S}_{3}$ menyelesaikan soal dengan cara mengeliminasi variabel $\mathrm{x}$ terlebih dahulu untuk memperoleh nilai variabel y kemudian menggunakan metode substitusi untuk mencari nilai cariabel $\mathrm{x}$. Kemudin $\mathrm{S}_{3}$ disini salah dalam menuliskan simbol min (-) yang di mana seharusnya tidak perlu.

\section{Langkah IV melakukan pengecekan kembali terhadap semua langkah yang telah di kerjakan}

Pada langka ini di harapkan siswa mampu memeriksa hasil perhitungan yang di peroleh dan menafsirkan hasil perhitungan sebagai kesimpulan yang bisa menjawab ini permasalahan yang di hadapi oleh siswa.

Berikut adalah hasil kajian kemampuan siswa dalam menyelesaikan soal Sistem Persamaan Linear Dua Variabel siswa kelas VIII SMPN 18 Mataram dengan langkah pemecahan masalah Polya.

Berdasarkan dari hasil penelitian secara keseluruhan, dapat diketahui bahwa pada umumnya kemampuan pemecahan masalah siswa pada soal cerita masih sangat rendah. Kurangnya kemampuan siswa dalam memahami masalah (menuliskan apa yang diketahui dan apa yang ditanyakan), merencanakan penyelesaian (membuat model matematika), melakukan rencana penyelesaian, dan memeriksa kembali prosedur dan hasil penyelesaiannya menyebabkan siswa kesulitan dalam memecahkan suatu permasalahan yang di berikan dalam bentuk soal cerita (Novi, Zubaidah, \& Romal). 
Berikut penjabaran mengenai kemampuan pemecahan masalah siswa dalam menyelesaikan soal Sistem Persamaan Linear Dua Variabel (SPLDV) berdasarkan tahapan polya:

\section{a. Memahami masalah}

Pada langkah pertama ini, pemecahan masalah harus dapat menentukan apa yang di ketahui dan apa yang di tanyakan. Untuk mempermudah pemecahan masalah memahami masalah dan memperoleh gambaran umum penyelesaiannya.

Pada soal nomor $1 \mathrm{~S}_{1}$, dan $\mathrm{S}_{2}$ mengalami kesulitan dalam memahami soal cerita yang dimana $S_{1}$ menuliskan barangnya sebagai variabel, padahal untuk variabel itu yang harus di tuliskan bentuk kuantitasnya misalkan, seperti banyaknya pensil atau harga pensil. Terdapat kesalahan konsep dalam permisalan variabel pada model matematika yang mampu siswa buat dari soal yang diberikan. Siswa membuat permisalan variabel yang digunakan dalam model matematikatidak sesuai dengan data yang diketaui dan yang ditanyakan. $S_{1}$ dan $S_{2}$ memisalkan pensil = x dan penggaris = yyang seharusnya di tuliskan harga pensil $=\mathrm{x}$ dan harga penggaris $=\mathrm{y}$. Kesalahan seperti ini di kenal sebagai kesalahan konsep (Herutomo \& Saputro, 2014). Sedangkan $\mathrm{S}_{3}$ disini tidak menuliskan apa yang diketahui dan apa yang ditanyakan. Gejala lupa mudah terjadi pada pengetahuan kognitif bila individu tidak berhasil mengonstruksi pengetahuannya sendiri atau mengaitkan pengetahuan yang telah di pelajarinnya dengan pengetahuan yang telah di miliinya atau disebabkan oleh cara guru mengajar yang masih menggunakan cara konvensional sehingga siswa cenderung pasif dan semua pembelajaran berpusat pada guru (Mahmuzah, Ikhsan \& Yuzrizal, 2014).

Pada soal nomor $2, \mathrm{~S}_{1}$ masih keliru dalam pemisalannya padahal untuk variabelnya itu yang harus di tulis bentuk kuantitasnya misalkan seperti jam kerja lisa atau jam kerja murni. Sedangkan $S_{2}$ dan $S_{3}$ sudah bagus dalam pemisalannya atau sudah di jam kerjanya disini dan ini sudah tepat untuk pemisalannya.

\section{b. Merencanakan penyelesaian}

Pada langkah ini siswa memilih bentuk formula yang terkait untuk solusi pemecahan masalah dan menuliskan kondisi yang harus dipenuhi untuk solusi pemecahan masalah. 
Siswa diharapkan mampu memilih strategi yang tepat untuk menemukan solusi pemecahan dari sistem persamaan linear dengan memilih salah satu dari empat metode penyelesaian sistem persamaan linear dibawah ini, yaitu:

1. Menggunakan metode grafik

2. Menggunakan metode subtitusi

3. Menggunakan metode eliminasi

4. Menggunakan metode campuran

Dalam perencanaan penyelesaian ini tidak bisa kita telusuri terlebih jauh karna yang di analisis adalah lembar kerja siswanya yang mana pada lembar kerja itu sebenarnya sudah si siswa atau sih sabjek penelitian ini sudah langsung melakukan rencana penyelesaiannya . kalau untuk rencana ini seharusnya ditanyakan sebelum siswa mengerjakan tetapi ketidak mampuan kita dalam mewawancarai siswa kita tidak bisa mengetahui secara pasti sebelumnya siswa rencanakan. Sehingga, kita bisa menganalisisnya melalui tahap pelaksanaannya saja dan hasilnnya adalah misalkan siswa $\mathrm{S}_{1}$ menggunakan metode campuran dan substitusi.Sama juga dengan $\mathrm{S}_{2}$ hal ini dapat dilihat dari langkah pertama misalkan harus disuebut langkah pertama pengeliminasian variabel yang kemudian di lanjutkan dengan persubstitusian hasil eliminasi yang dilakukan tadi dari hasil variabel terntentu yang di peroleh dari hasil eliminasi dari hasil variabel lainnya itu yang di substitusi. Kemudian $S_{3}$ menggunakan metode substitusi dengan langsung memasukan nilai dari variabel-variabelnya.

\section{c. Melakukan rencana penyelesaian}

Pada langkah ini siswa dapat memenuhi kondisi yang harus dipenuhi dan melakukan perhitungan dengan tepat melalui metode penyelesaian yang sudah dipilih siswa. Pada soal nomor $1 \mathrm{~S}_{1}$ menyelesaikan soal dengan cara mengeliminasi varibel y terlebih dahulu untuk memperoleh nilai variabel x kemudian menggunakan metode substitusi untuk mencari nilai variabel $x$. Setelah mendapatkan kudua nilai variabel tersebut $\mathbf{S}_{2}$ kemudian mensubstitusikan nilai kedua variabel untuk mendapatkan hasilnya. Kemudain untuk mendapatkan hasil dengan cara mensubstitusikan nilai dari variabel $\mathrm{x}$ dan y $S_{1}$ memulai menggunakan tanda sama dengan padahal tanda sama dengan ini untuk hubungan ekupalensi antara ruas kiri dan ruas kanan. Sedangkan ruas kiri tidak ada apa-apa tiba-tiba menuliskan sama dengan, ini hal yang tidak perlu dilakukanoleh 
$S_{1}$ disini. Pada soal nomor $2 S_{1}$ menyelesaikan soal dengan cara mengeliminasi variabel $\mathrm{y}$ terlebih dahulu untuk memperoleh nilai variabel $\mathrm{x}$ kemudian menggunakan metode substitusi untuk mencari nilai variabel y.

Pada soal nomor $1 \mathrm{~S}_{2}$ menyelesaikan soal dengan cara mengeliminasi variabel y terlebih dahulu untuk memperoleh nilai vaiabel y kemudian menggunakan metode substitusi untuk mencari nilai variabel x. Setelah mendapatkan kedua nilai variabel tersebut $\mathrm{S}_{2}$ kemudian mensubstitusikan nilai kedua variabel untuk mendapatkan hasilnya. Pada tahap pengeliminasian variabel disini benar, namun $S_{2}$ salah dalam menuliskan persamaan pertama. Sehingga berdampak pada hasilnya. Hasil analisis lembar jawaban siswa juga menunjukkan bahwa siswa melakukan kesalahan dalam mentransformasi informasi pada soal atau memahami setiap arti dari kata dalam soal, sehingga bentuk kesalahan seperti ini dapat di katagorikan sebagai kesalahan membaca (Islamiyah, Prayitno, \& Amrullah, 2017). Pada soal nomor $2 S_{2}$ menyelesaikan soal dengan cara mengeliminasi variabel $\mathrm{x}$ terlebih dahulu untuk memperoleh nilai variabel y kemudian menggunakan menggunakan metode substitusi untuk mencari nilai variabel $\mathrm{X}$.

Pada soal nomor $1 \mathrm{~S}_{3}$ menyelesaikan soal dengan cara mensubstitusikan nilai $\mathrm{x}$ dan $\mathrm{y}$ untuk mendapatkan hasilnya. Namun untuk yang $S_{3}$ ini, $S_{3}$ tidak menuliskan cara mendapatkan nilai variabel $\mathrm{x}$ dan y jadi kita tidak paham apakah $\mathrm{S}_{3}$ mengetahui apa yang di ketahui dan ditanyakan. Tetapi, ketika di telusi jawabannya berhasil mengerjakan jawaban dengan hasil yang benar atau seharusnya. Gejala lupa mudah terjadi pada pengetahuan kognitif bila individu tidak berhasil mengonstruksi pengetahuannya sendiri atau mengaitkan pengetahuan yang telah di pelajarinnya dengan pengetahuan yang telah di miliinya atau disebabkan oleh cara guru mengajar yang masih menggunakan cara konvensional sehingga siswa cenderung pasif dan semua pembelajaran berpusat pada guru (Mahmuzah, Ikhsan \& Yuzrizal, 2014). $S_{3}$ menyelesaikan soal dengan cara mengeliminasi variabel $\mathrm{x}$ terlebih dahulu untuk memperoleh nilai variabel y kemudian menggunakan metode substitusi untuk mencari nilai cariabel $x$. Kemudin $S_{3}$ disini salah dalam menuliskan simbol min (-) yang di mana seharusnya tidak perlu. 


\section{d. Memeriksa kembali}

Pada langka ini di harapkan siswa mampu memeriksa hasil perhitungan yang di peroleh dan menafsirkan hasil perhitungan sebagai kesimpulan yang bisa menjawab ini permasalahan yang di hadapi oleh siswa.

\section{SIMPULAN DAN SARAN}

Kemampuan pemecahan masalah siswa dalam menyelesaikan soal SPLDV siswa sebenarnya mampu dalam menyelesaikan soal SPLDV berdasarkan tahapan-tahapan penyelesaian masalah Polya seperti menyebutkan yang diketahui dan yang ditanyakan soal, membuat model matematika dri soal yang diberikan dan memilih metode yang akan digunakan untuk menyelesaikan soal yang diberikan dilanjutkan dengan melaksanakan rencana penyelesaian yang telah dibuat dan diakhiri dengan memeriksa kembali jawaban yang telah diperoleh. hanya saja tidak mampu pada saat menyebutkan yang diketahui.

Berdasarkan hasil penelitian yang telah dilaksanakan, didapatkan beberapa saran sebagai berikut.

1. Bagi guru bidang studi, dalam pelaksanaan pembelajaran diharapkan untuk membuat pengembangan model soal dan variabel, sehingga siswa memiliki tambahan informasi agar siswa tidak hanya terfokus pada model soal yang sama.

2. Bagi siswa yang melakukan kesalahan memahami soal, sebaiknya lebih cermat dan teliti lagi dalam membaca soal.

3. Bagi siswa yang melakukan kesalahan dalam menyusun rencana, sebaiknya lebih dibiasakan untuk menyusun rencana sebelum menyelesaikan soal cerita yang diberikan seperti membuat pemisalan variabel, membuat model matematika dari kalimat cerita yang diberikan, menentukan metode yang akan digunakan dan langkah-langkah yang akan digunakan dalam menyelesaikan model matematika yang telah dibuat.

Bagi siswa yang melakukan kesalahan dalam melaksanakan rencana, sebaiknya lebih teliti dalam melakukan perhitungan matematika dalam menyelesaikan model matematika yang telah dibuat serta menentukan kesimpulan terhadap permasalahan yang diberikan.

\section{DAFTAR PUSTAKA}

Anwar, S., \& Amin, M. S. (2013) penggunaan langkah pemecahan masalah polya dalam menyelesaikan soal cerita pada materi perbandingan di kelas VI MI al-ibrohimmy galis bangkalan. Jurnal Pendidikan Matematika, I (1),1-6. 
Bidasar, F. (2017). Pengembangan soal matematika model pisa pada konten quantity untuk mengukur kemampuan pemecahan masalah matematika siswa sekolah menengah pertama.

Depdiknas. (2005). Peraturan pemerintah Republik Indonesia Nomor 19 tahun 2005 tentang Standar Pendidikan Nasional. Jakarta: Depdiknas.

Herutomo, R. A., \& Saputro, T. E. M. (2014). Analisi kesalahan dan miskonsepsi siswa kelas VIII pada materi aljabar. Jurnal Pendidikan Dan Pembelajaran, 1(2), 134145.

Islamiyah, A. C., Prayito, S., \& Amrullah. (2017). Analisi kesalahan siswa SMP pada penyelesaian masalah sistem persamaan linear dua variabel. Jurnal Didaktik Matematika, 5(1), 66-76.

Mahmuzah, R., Ikhsan, M., \& Yusrizal. (2014). Penigkatan kemampuan berpikir kritis dan di posisi matematisnsiswa SMP dengan menggunakan pendekatan problem posing. Jurnal Didaktik Matematika, 1(2), 43-53.

Ngilawayan, D. A. (2013). Proses berfikir siswa SMA dalam memecahkan masalah matematika materi turunan ditinjau dari gaya kognitif field independent dan field dependent PEDAGOGIA: Jurnal Pendidikan, 2 (1), 71-83.

Norlismasari, Johar, R., \& Yusrizal. (2017). Optimisme siswa SMP dalam menyelesaikan soal problem solving. Jurnal Didaktif Matematika, 4(1), 53-58.

Polya, G. (1973). How tosolve it a new aspect of mathematical methoe. New Jersey: Princeton University Pres.

Yani, M., Ikhsan, \& Marwan. (2016). Proses berfikir siswa dalam memecahkan masalah matematika berdasarkan langkah-langkah polya ditinjau dari adversity quotient. Jurnal Pendidikan Matematika, 10(1), 43-58

Yanti, A. P., \& Syazali, M. (2016). Analisi proses berfikir siswa dalam memecahkan masalah matematika berdasarkan langkah-langkah bransford dan stein ditinjau dari adversity quotient. Al-Jabar: Jurnal Pendidikan Matematika, 7(1), 63-74. 